\title{
乳用雄子牛と雌子牛の発育段階における血清のビタミン $\mathrm{A}$, ビタミン $\mathrm{E}$, セレニウム，脂質分画および血液グルタチオンペルオキシダーゼ活性の変化
}

\author{
井上理人一条 茂 納 敏 更科孝夫 \\ 帯広畜産大学畜産学部（帯広市稲田町， $\mathbf{T} 080$ ) \\ (平成 2 年 9 月 21 日受付・平成 3 年 3 月 22 日受理)
}

\begin{abstract}
Changes of Serum Vitamin A, Vitamin E, Selenium, Lipid Compositions and Blood Glutathioneperoxidase Activity during the Growth Stage of Holstein Bull Calves and Heifer Calves Michito Inoue, Shigeru Ichijo, Satoshi Osame and Takao Sarashina (Obihiro University of Agriculture and Veterinary Medicine, Obihiro, Hokkaido 080)
\end{abstract}

\section{SUMMARY}

Ninety bull calves for fattening and thirty heifer calves of the Holstein breed were classified into five growth stages (stage I: 7 days old; stage II: 1 month old; stage III: 3 months old; stage IV: 6 months old; stage V: 12 months old; stage VI: 17 to 18 months old) and blood chemical components including serum lipid fractions, vitamin A, vitamin $\mathrm{E}$ (tocopherol), selenium and blood glutathioneperoxidase activity were examined during each of these growth stages.

During the fattening stage (stage V to VI) of bull calves, serum lipid fractions including total lipid, phospholipid, total cholesterol, ester cholesterol and lipid peroxide, and serum tocopherol levels increased significantly compared with the levels of heifer calves in the same growth stages, but the levels of serum retinol and erythrocyte tocopherol decreased to the contrary. There were many correlations between the level of serum tocopherol and the serum lipid compositions including phospholipid, total cholesterol and total lipid. The increase in the serum lipid levels during the fattening stage of bull calves seemed to reflect the development of the fatty tissue. Also, the decrease in erythrocyte tocopherol which is an indication of bioavailable tocopherol might be caused by the increase in the shift to fatty tissue of tocopherol.

The serum selenium level and blood glutathioneperoxidase activity decreased markedly from stage $\mathrm{V}$ to VI for the heifer calves, and it was suggested that the decrease in both blood components was due to the low selenium diet. — Key Words : calf, selenium, vitamin A, vitamin E, lipid fraction.

J. Jpn. Vet. Med. Assoc., 44, 887 892 (1991)

要 約

肥育用乳用雄子牛と乳用雌子牛を発育段階で 5 期（I 期： 7 日齢, II 期：1 力月齢， IIII期：3 力月齢, IV期：6 力 月齢, $\mathrm{V}$ 期：12 力月齢, $\mathrm{VI}$ 期：17〜 18 力月齢）に分け, 各発育段階での血清のビタミン $\mathrm{A}$, ビタミン $\mathrm{E}$, セレニウ ム, 各脂質成分值拉よび血液グルタチオンペルオキシダーゼ活性の変化を検討した.

乳用雄子牛では肥育期（V〜VI期）に血清脂質成分（総脂質, リン脂質, 総コレステロール, コレステロールェス テル, 過酸化脂質）と血清トコフェロール值が乳用雌と比べ有意に増加し, 反対に血清レチノールと赤血球トコフェ ロール值は明瞭に減少した。 また, 血清トコフェロール值と血清脂質成分（リン脂質, 総コレステロール, 総脂質) 值の間には高い正の相関がみられた。

乳用雄子牛の肥育期における血清脂質成分の増加は，この時期の体脂肪組織の発達を反映したものであり，この時 期における生体利用型の赤血球トコフェロールの減少は生体内トコフェロールが脂肪組織に多量移行したためと考え られた。 なお，血清セレニウムと血液グルタチオンペルオキシダーゼ活性值は乳用雌子牛の V〜VI期に明瞭に減少し たが, 原因はこの時期の給与飼料中のセレニウム含量の低下によるものと考えられた.

一キーワード: 子牛, セレニウム, ビタミン $\mathrm{A}$, ビタミン $\mathrm{E}$, 脂質分画. 
乳用雄子牛と雌子牛の発育段階における血清のビタミン A, E， セレニウム, 脂質分画および血液グルタチオンペルオキシダーゼ活性の变化

最近のホルスタイン種牛では, 雌子牛 (乳用雌) は乳 牛, 雄子牛 (乳用雄) は肉牛として飼育されている. 特 に乳用雄の肉用肥育では早期肥育が目的の不断給䭒が行 われるため, 濃厚飼料の過給に起因する脂肪肝, 肝膿瘍, 食䬣性蹄葉炎, 尿石症等が多発し, これらによる経済損 失の増加が注目されている.

肥育牛のボディコンディション判定には各肥育段階に おける代謝の状況を知るうえで血液諸成分の変化が参考 となるが，これまでこの方面の基礎デー夕は非常に乏し (16).

われわれは, 牛の早期肥育や肥満が血液の特に脂質関 係成分に及ぼす影響を知る目的で，主として乳用雄の肥 育段階および乳用雌の発育段階での变化について比較検 討を行った。

\section{材料および方法}

\section{供試牛}

北海道十勝地方の Oフィードロット牛舎で飼育され ている臨床的に健康な乳用雄 90 頭を用いた。供試牛を 発育段階により I 期 : 哺育期 ( 7 日齢), II 期：離乳期 ( 1 力月齢), III期 : 育成前期 ( 3 力月齢), IV 期 : 育成 後期 ( 6 力月齢), $\mathrm{V}$ 期 : 肥育前期 (12 力月齢), $\mathrm{VI}$ 期 : 肥育後期 $(17 \sim 18$ 力月齢) の各群に分け, 各群 15 頭ずつ血液を採取した，また，乳用此は帯広畜産大学附 属農場で飼養されている 30 頭を乳用雄之同様に 6 期の 発育段階各群 5 頭に分けて, 血液を採取した。

供試牛の給与飼料は, 乳用雄では I 期は初乳のみ, II 期は代用乳とスターター (哺育期配合飼料), III 期以後 は乾草と配合飼料の不断給餌を行った. 肥育終了時 (17 〜 18 力月齢）の体重は平均 $650 \mathrm{~kg}$ と過肥状態であった. 乳用雌には, I, II 期は初乳と全乳, III 期以降は乾草, コーンサイレージ，ヘイレージを主体として給与した。 実験終了時（17〜 18 力月齢）には体重が平均 $410 \mathrm{~kg}$ と乳用雄と比べ大差がみられた。 また, 乳用雄には, 7 日, 15 日拉よび 40 日齢の時にビタミン $\mathrm{AD}_{3} \mathrm{E}$ プレミッ クス (液剤 $1 \mathrm{~m} l$ 中にビタミン A 50, $000 \mathrm{IU}$, ビタミン $\mathrm{D}_{3} 10,000 \mathrm{IU}$, ビタ ミン $\mathrm{E} 40 \mathrm{mg}$ を含有) $10 \mathrm{ml}$, さらに 3 力月齢と 4.5 力月齢時に $20 \mathrm{~m} l$ と計 5 回の投与 を行った.

\section{検 查 項 目}

血液成分の検查項目と方法は次のとおりとした，血清 ビタミン A (レチノール, レチニルパルミテート): 高 速液体クロマトグラフ法帛, 血清トコフェロール: 螢 光法 ${ }^{2)}$, 赤血球 $\alpha$-トコフェロール：石橋らの高速液体ク ロマトグラフ ${ }^{1 A^{11)}}$, 血清セレニウム: 螢光法 ${ }^{24,25)}$, 血液 グルタチオンペルオキシダーゼ活性 (GSH-Px): Paglia \& Valentine 法 $^{27)}$, 血清過酸化脂質 (LPO) : TBA 法 ${ }^{13)}$, 総コレステロール (TC) およびコレステロールエステル

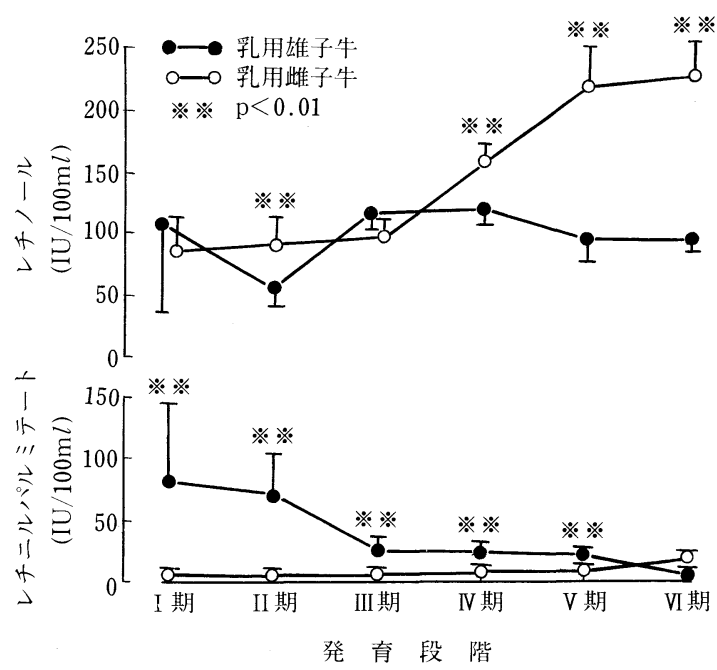

図 1 乳用雄子牛之雌子牛の発育段階における血清 レチノールとレチニルパルミテート值の変化

(EC) : 酵素法, リン脂質 $(\mathrm{PL})$ ：酵素法, トリグリセラ イド (TG): 酵素法, 遊離脂肪酸 (FFA) : ACS-ACOD 法の 12 項目について測定した。 なお, 血清総脂質 (TL) は各血清脂質成分を加算して求めた。 その場合, FFA は $1 \mathrm{mEq} / \mathrm{L}=28.25 \mathrm{mg} / 100 \mathrm{~m} l$ として換算した.

各性別群と雌雄群の平均値の差の検定は Student の $\mathrm{t}$ 検定法によって行った.

\section{成績}

\section{血清ビタミン A}

血清レチノール值 (図 1) は, 乳用雄では全体的に各 発育段階群の間で有意な差は認められなかった。しかし，

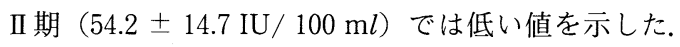
これに対し乳用雌では，IV〜VI期群はI， II， III期群に 比べ有意 $(\mathrm{P}<0.01)$ な増加を示し, 特に V 期と VI期群 は著明であったささらに乳用雄群と比較すると II 期, IV 期，V期とVI期群間で高い值を示した。

血清レチニルパルミテート值（図1）は, 乳用雄では I 期 $(82.3 \pm 63.6 \mathrm{IU} / 100 \mathrm{~m} l) ， \quad$ II 期 $(71.9 \pm 35.4 \mathrm{IU} /$ $100 \mathrm{~m} l)$ が高值で，以後は減少してV期は $14.8 \pm 7.0$ $\mathrm{IU} / 100 \mathrm{ml}$, VI期では測定限界值以下となった。これに 対し, 乳用雌では全期群ともほぼ同様な程度で各群間に 差を認めず, 乳用雄と比べ有意 $(\mathrm{P}<0.01)$ には低值を 示したが，VI期には乳用雄群との間には差を認めなかっ た。

\section{血清 Toc 值と赤血球 $\alpha$-Toc 值}

血清 Toc 值（図 2) は, 乳用雄では I 期（181.9 土 $118.6 \mu \mathrm{g} / 100 \mathrm{ml})$ に比べ II 期 $(76.0 \pm 21.0 \mu \mathrm{g} / 100$ $\mathrm{m} l)$ から $\mathrm{IV}$ 期 $(78.0 \pm 21.0 \mu \mathrm{g} / 100 \mathrm{~m} l)$ で低く, $\mathrm{V}$ 期 $(196.5 \pm 43.8 \mu \mathrm{g} / 100 \mathrm{ml})$, VI期 $(201.1 \pm 43.3 \mu \mathrm{g} / 100$ 

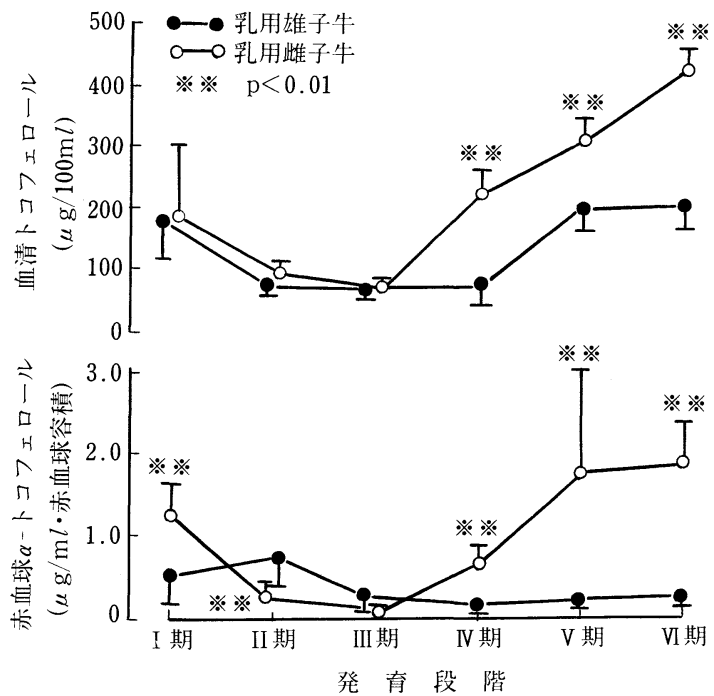

図 2 乳用雄子牛と雌子牛の発育段階における血清 トコフェロールと赤血球 $\alpha$-トコフェロール值の 変化

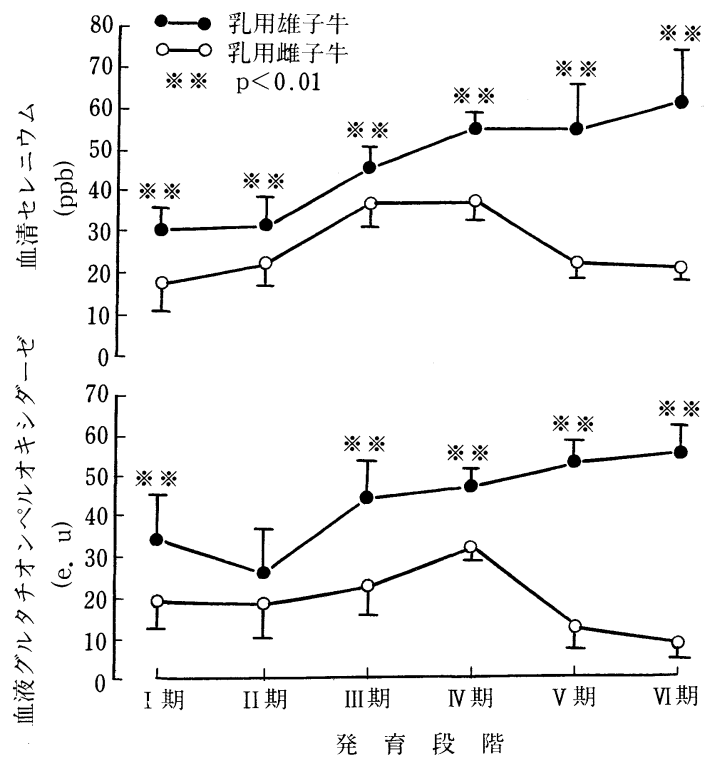

図 3 乳用雄子牛之雌子牛の発育段階における血清 セレニウムと血液グルタチオンペルオキシダー ゼ活性值の変化

$\mathrm{m} l$ ) では I 期とほぼ同様の值を示した。乳用雌では I 期 $(185.6 \pm 121.0 \mu \mathrm{g} / 100 \mathrm{ml})$ から III 期（70.7 \pm 13.3 $\mu \mathrm{g} / 100 \mathrm{ml}$ ) までは乳用雄とほとんど同様の変化を示し たが， IV期 $(219.0 \pm 41.8 \mu \mathrm{g} / 100 \mathrm{ml})$ から VI期（424.0 $\pm 29.0 \mu \mathrm{g} / 100 \mathrm{ml}$ ) 群ではその濃度は I〜III 群に比べ 有意に高い值を示した. また, 乳用雄に比べても有意に 高值を示した。

赤血球 $\alpha$-Toc 值（図 2 ）は, 乳用雄では I 期（0.49

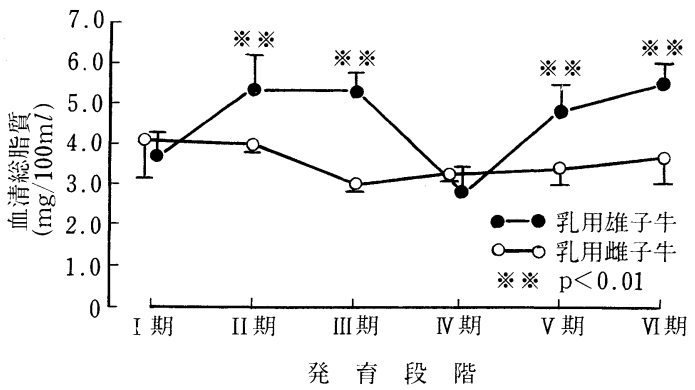

図 4 乳用雄子牛と雌子牛の発育段階における血清 過酸化脂質の変化

$\pm 0.34 \mu \mathrm{g} / \mathrm{m} l$ 赤血球容積 $), \quad$ II 期 $(0.76 \pm 0.42 \mu \mathrm{g} / \mathrm{m} l$ 赤血球容積）以降に明瞭に減少して，特にIV，V，VI期 ではそれぞれ $0.13 \pm 0.05,0.20 \pm 0.08$ ならびに $0.22 \pm$ $0.12 \mu \mathrm{g} / \mathrm{m} l$ 赤血球容積と低值を示した. これに対し, 乳用雌では I期群で低下しはじめ，さらに亚期群で著明 に低下した。しかし，V，VI期群では他群より著明に増 加した。 また, 乳用雄と比較すると特にV 期（1.75 士 $1.25 \mu \mathrm{g} / \mathrm{m} l$ 赤血球容積）とVI期（1.91 $\pm 0.49 \mu \mathrm{g} / \mathrm{m} l$ 赤血球容積）で高値であった．乳用此における血清 Toc と赤血球 $\alpha$-Toc の全期での変動は同様の状態を示 した。

\section{血 清 Se 值}

乳用雄の血清 Se 值（図 3 ）は I 期（29.8 $\pm 5.2 \mathrm{ppb）,}$ II 期（30.5 土6.8 ppb）に比べIII期以降に増加する傾向

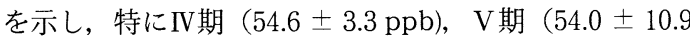

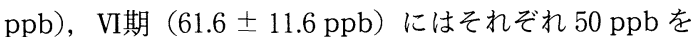
上回る值を示した。これに対し，乳用雌では I 期（16.8 $\pm 6.5 \mathrm{ppb}) ， \quad$ II 期， $\quad \mathrm{V}$ 期 $(21.1 \pm 2.3 \mathrm{ppb}) ， \quad \mathrm{IV}$ 期（19.9 土2.7 ppb）はほぼ同じ濃度であったが， IIII期（36.1

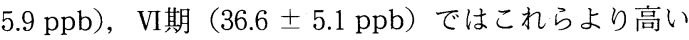
值を示した，雄群と比較するといずれの発育段階におい て屯雌群の方が雄群より有意 $(\mathrm{P}<0.01)$ に低く, 平均 值では $40 \mathrm{ppb}$ 以下であった.

\section{血液 GSH-Px 活性値}

乳用雄の血液 GSH-Px 活性（図 3 ）は I 期（33.3 土

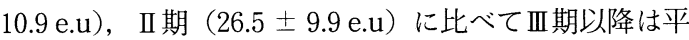

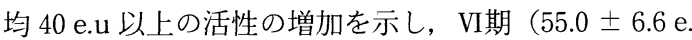
u）に最高值を示した。乳用雌は全期間をつうじて乳用 雄と比べ有意 $(\mathrm{P}<0.01)$ に低值で, IV期 $(31.5 \pm 3.2 \mathrm{e}$. u）を除きすべて平均 $30 \mathrm{e} . \mathrm{u}$ 以下であり，特に V 期

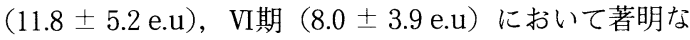
低活性を示した.

\section{血清 Se 值と血液 GSH-Px 活性値の関係}

血清 Se 值と血液 GSH-Px 活性值の変動はほぼ平行 し, 両者間には高い正の相関 $(\gamma=0.81, \mathrm{n}=120, \mathrm{P}$ ＜0.01）が認められた。 


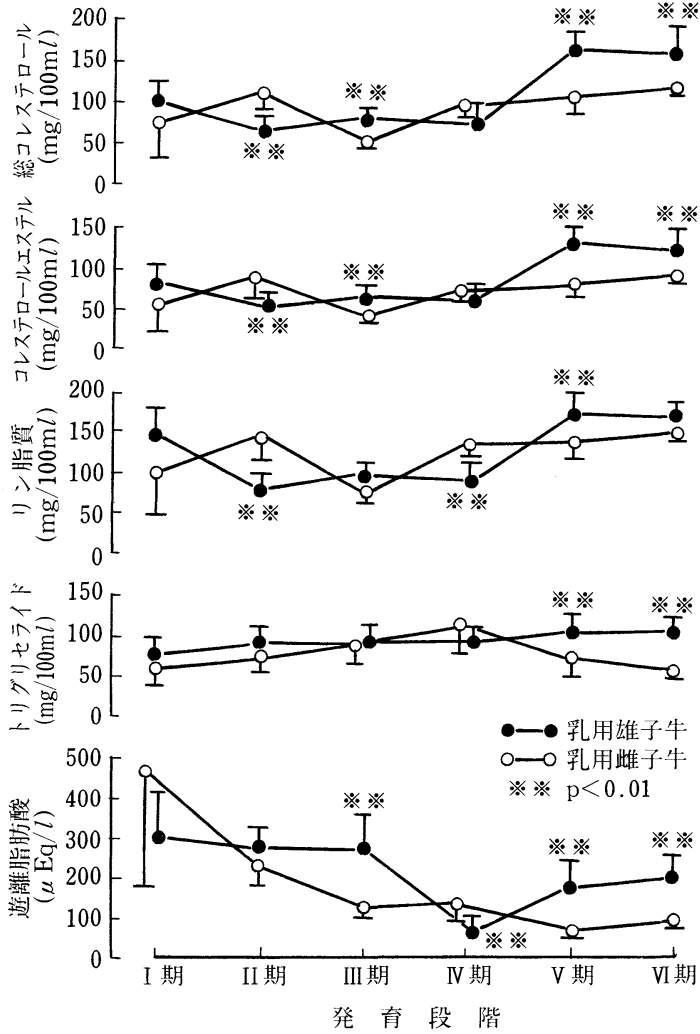

図 5 乳用雄子牛と雌子牛の発育段階における血清 総コレステロール，エステルコレステロール， リン脂質, トリグリセライド，遊離脂肪酸值の 変化

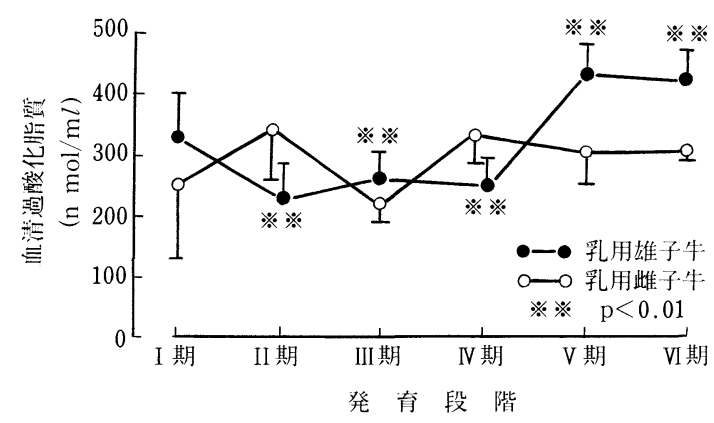

図 6 乳用雄子牛と雌子牛の発育段階における血清 総脂質値の変化

\section{血 清 LPO}

乳用雄の血清 LPO（図 4 ）は I 期（3.71 $\pm 0.58 \mathrm{nmol}$ $/ \mathrm{m} l)$ とIV期 $(2.91 \pm 0.5 \mathrm{nmol} / \mathrm{ml})$ で低く，他の時期 に高値（II 期 : $5.38 \pm 0.80 \mathrm{nmol} / \mathrm{ml}$, III 期 : $5.36 \pm$ $0.42 \mathrm{nmol} / \mathrm{ml}, \quad \mathrm{V}$ 期 : $4.84 \pm 0.65 \mathrm{nmol} / \mathrm{ml}$, VI 期 : $5.53 \pm 0.56 \mathrm{nmol} / \mathrm{ml}$ ) を示した.これに対し乳用雌は, I 期に最高值 $(4.16 \pm 0.98 \mathrm{nmol} / \mathrm{ml})$ で，以降は減少
して, II, III，V，VI期では同時期の乳用雄と比べて有 意 $(\mathrm{P}<0.01)$ な低値を示した.

\section{血清コレステロール}

血清 TC 值（図 5 ）は, 乳用雄では, I 期（102.4 土 $24.7 \mathrm{mg} / 100 \mathrm{ml}$ ) に比べて I〜 IV 期に減少（II期： $65.4 \pm 15.3 \mathrm{mg} / 100 \mathrm{ml}, \quad$ III 期 : $74.8 \pm 13.0 \mathrm{mg} / 100$ $\mathrm{m} l$, IV 期 : $73.9 \pm 19.0 \mathrm{mg} / 100 \mathrm{ml}$ ) したが, $\mathrm{V}$ 期 $(159.6 \pm 22.1 \mathrm{mg} / 100 \mathrm{ml})$ とVI期 $(151.9 \pm 26.3 \mathrm{mg} /$ $100 \mathrm{ml}$ ) で増加が明瞭であった。乳用雌では各期群間に ほとんど差を認めなかった他, 乳用雄群と比較すると II 期 $(109.2 \pm 26.3 \mathrm{mg} / 100 \mathrm{ml})$ では乳用雄よりも上昇 したが， V 期 $(100.7 \pm 20.0 \mathrm{mg} / 100 \mathrm{ml})$ と VI期群 $(111.6 \pm 8.5 \mathrm{mg} / 100 \mathrm{ml})$ では低值を示した.

血清 EC 値（図 5 ）は TC 值とほぼ類似の变動を示し, 乳用雄では乳用雌に比べ V 期 $(125.8 \pm 18.3 \mathrm{mg} / 100$ $\mathrm{m} l)$ とVI期 $(117.6 \pm 22.7 \mathrm{mg} / 100 \mathrm{ml})$ に有意 $(\mathrm{P}$ <0.01）な高值がみられた.

\section{血清 FFA 値}

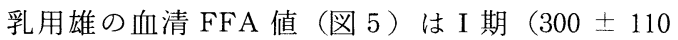
$\mu \mathrm{Eq} / \mathrm{L})$ から III 期 $(270 \pm 80 \mu \mathrm{Eq} / \mathrm{L})$ にかけて高值で, 以後は減少して $\mathrm{IV}$ 期に最低值 $(70 \pm 30 \mu \mathrm{Eq} / \mathrm{L})$ となり, $\mathrm{VI}$ 期は $200 \pm 50 \mu \mathrm{Eq} / \mathrm{L}$ とや>増加した。 乳用雌では I 期 $(470 \pm 290 \mu \mathrm{Eq} / \mathrm{L})$ が最高值で, 以後は発育段階が 進むにつれて減少し， $\mathrm{V}$ 期 $(60 \pm 10 \mu \mathrm{Eq} / \mathrm{L})$ とI期 $(90 \pm 20 \mu \mathrm{Eq} / \mathrm{L})$ では同時期の乳用雄より低い值を示し た.

\section{血 清 TG 値}

血清 TG 值（図 5 ）は, 乳用雄では I 期（74.7 \pm 21.5 $\mathrm{mg} / 100 \mathrm{~m} l)$ に最低值で, 以後は発育に伴いゆるやか な増加傾向を示し, VI期 $(103.7 \pm 13.0 \mathrm{mg} / 100 \mathrm{ml})$ に最高值となった。乳用雌では I 期 $(60.6 \pm 24.8 \mathrm{mg} /$ $100 \mathrm{ml})$ 以降増加して, IV 期 $(110.3 \pm 34.6 \mathrm{mg} / 100$ $\mathrm{ml}$ ）に最高值となった後は $\mathrm{V}$ 期 $(70.0 \pm 28.0 \mathrm{mg} / 100$ $\mathrm{m} l)$, VI期 $(53.2 \pm 7.5 \mathrm{mg} / 100 \mathrm{ml})$ には同時期の乳用 雄と比べ有意な低值であった。

\section{血 清 PL 值}

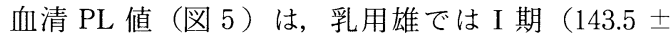
$36.6 \mathrm{mg} / 100 \mathrm{ml}$ ) と比べて II 〜 IV 期に減少（II期： $76.6 \pm 19.2 \mathrm{mg} / 100 \mathrm{ml}$, III 期 : $89.0 \pm 16.5 \mathrm{mg} / 100$ $\mathrm{m} l$, IV 期 $: 87.6 \pm 19.7 \mathrm{mg} / 100 \mathrm{ml}$ ) したが, $\mathrm{V}$ 期 $(165.8 \pm 20.9 \mathrm{mg} / 100 \mathrm{ml})$ ， VI 期 $(159.3 \pm 22.1 \mathrm{mg} /$

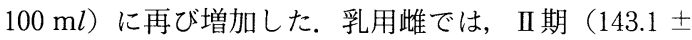
$31.2 \mathrm{mg} / 100 \mathrm{ml})$ と IV 期 $(126.3 \pm 11.1 \mathrm{mg} / 100 \mathrm{ml})$ に乳用雄より高值で，V，VI期は乳用雄より低值であっ た.

\section{血 清 TL 值}

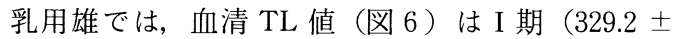
$72.7 \mathrm{mg} / 100 \mathrm{ml}$ ) に比べて II〜 IV 期に減少（II期： 
井上理人一条茂 納

表 1 血清トコフェロールと血清脂質成分の濃度の相関

\begin{tabular}{lcccc}
\hline \hline \multicolumn{1}{c}{ 脂 質 成 分 } & $\mathrm{n}$ & 相関係数 & 有 意差 \\
\hline 総 & 脂 質 & 119 & 0.52 & $\mathrm{p}<0.01$ \\
総コレステロール & 119 & 0.55 & $\mathrm{p}<0.01$ \\
トリグリセライド & 119 & -0.08 & $\mathrm{p}>0.25$ \\
リ ン 脂 質 & 119 & 0.65 & $\mathrm{p}<0.01$ \\
遊 離 脂 肪 酸 & 119 & -0.17 & $\mathrm{p}<0.10$ \\
\hline
\end{tabular}

表 2 赤血球 $\alpha$-トコフェロールと血清トコフェロール/血 清脂質成分の相関

\begin{tabular}{|c|c|c|c|}
\hline 脂 質 成 分 & $\mathrm{n}$ & 相関係数 & 有意差 \\
\hline 脂 質 & 110 & 0.67 & $\mathrm{p}<0.01$ \\
\hline 総コレステロール & 110 & 0.70 & $\mathrm{p}<0.01$ \\
\hline トリグリセライド & 110 & 0.60 & $\mathrm{p}<0.01$ \\
\hline リン 脂 質 & 110 & 0.67 & $\mathrm{p}<0.01$ \\
\hline 遊離脂肪酸 & 110 & 0.44 & $\mathrm{p}<0.01$ \\
\hline
\end{tabular}

$236.8 \pm 51.8 \mathrm{mg} / 100 \mathrm{~m} l, \quad$ III 期 : $263.0 \pm 42.0 \mathrm{mg} / 100$ $\mathrm{m} l, \mathrm{IV}$ 期 $: 254.6 \pm 40.7 \mathrm{mg} / 100 \mathrm{ml})$ し, その後はV 期 $(429.7 \pm 53.2 \mathrm{mg} / 100 \mathrm{ml})$ とVI期 $(420.7 \pm 56.9$ $\mathrm{mg} / 100 \mathrm{ml}$ ) に増加した. 乳用雌では II 期 $(338.4 \pm$ $79.9 \mathrm{mg} / 100 \mathrm{ml})$ とIV期 $(330.2 \pm 46.4 \mathrm{mg} / 100 \mathrm{ml})$ に同時期の乳用雄より高值であったが, $\mathrm{V}$ 期 $(305.5 \pm$ $56.7 \mathrm{mg} / 100 \mathrm{ml})$, VI期 $(308.8 \pm 16.0 \mathrm{mg} / 100 \mathrm{ml})$ は 乳用雄が有意 $(\mathrm{P}<0.01)$ に高值であった.

\section{血清脂質成分と血清・赤血球 Toc 值の関係}

今回測定した各種の血清脂質成分と血清 Toc 值との 相関関係を表 1 に示した. 特に血清 Toc との相関度が 高い脂質成分は $\mathrm{PL}(\gamma=0.65, \mathrm{P}<0.01), \mathrm{TC}(\gamma=0.55$, $\mathrm{P}<0.01), \mathrm{TL}(\gamma=0.52, \mathrm{P}<0.01)$ の順であった. 次 に赤血球 $\alpha$-Toc と血清 Toc/血清脂質成分との相関を表 2 に示したが, 相関性の高いのは TC $(\gamma=0.70, \mathrm{P}$ $<0.01), \mathrm{PL}(\gamma=0.67, \mathrm{P}<0.01), \mathrm{TL} \quad(\gamma=0.67, \mathrm{P}$ $<0.01)$ 等であった.

\section{考察}

乳用雄の肥育段階における各血清脂質成分の変動を同 月齢の乳用雌と比較したところ, 乳用雄ではV 期（肥育 前期）からVI期（肥育後期）にかけて TL，PL，TC, $\mathrm{EC}$ の有意な増加が認められた. 乳用雄のこのような血 清脂質濃度の変化は, 恐らく牛の若齢肥育による体脂肪 の急速な蓄積を反映したものと考えられた．すなわち， 試験が終了したVI期（17〜 18 力月齢）の体重では, 乳 用雌が平均 $410 \mathrm{~kg}$ であったのに対し, 乳用雄は平均 $650 \mathrm{~kg}$ と明瞭な過肥状態であった。

このような乳用雄での变化を肉専用種の黒毛和種での 肥育時の変化に関する報告と比較すると, 黒毛和種では 血清の TL, PL, TC 等の増加が肥育前期 $(13 \sim 15$ 力 月齢）においてのみみられ，肥育後期（21〜28 力月 齢）では上記の血清脂質成分はむしろ減少し，代わって
TG, FFA が増加するとされている20,23). 以上のような 乳用雄と黒毛和種での血清脂質成分の变化の違いの理由 として, 品種, 遺伝要因, ホルモン制御等の諸要因の関 与屯軽視できないが, それ以上に両者の肥育期間の差異 で起る体脂肪の蓄積過程の違いに注目する必要があると 思われる.

すなわち, 血清 TL, PL, TC, EC の増加および FFA の減少を示す乳用雄の肥育前期と肥育後期, なら びに黒毛和種の肥育前期までの期間は不断給餌による TDN の摂取量の増加で皮下, 腸間膜, 筋肉膜等の脂肪 組織に脂肪が蓄積する時期である ${ }^{28,30)}$. 肥育期間がさら に延長する黒毛和種の肥育後期になると上記の体脂肪お よび血中脂質の著明な増加の結果, それらのエネルギー としての利用む行なわれるようになり, TG, NEFA が 血中に増加して ${ }^{20,23)}$, それらが内筋周囲膜間の脂肪組織 にも沈着して脂肪交雑が進み，いわゆる“サシ”が形成 されるものと考えられている14).

以上のように品種や肥育期間により多少の差はみられ るが, 牛の肥育が進むにつれ体脂肪の蓄積が増加するの で, それに伴い脂質の過酸化反応も六進する恐れが多い が，それを裏付けるように今回の乳用雄例では乳用雌例 と比べて血清 Lpo の有意な増加が認められた. したが って, このような Lpo の増加が脂質の過酸化抑制に対 して生体内での主役を果す有効利用型の Toc (bioavailable tocopherol) の消費および不足に影響を与え ないか否かの検討も必要である.

生体内での Toc には, 細胞膜系に局在して膜脂質の 抗酸作用として有効利用される Toc と, 血清の脂質成 分や体脂肪組織等の脂質プールに移行していて生体内で は非有効利用型である Toc (non-bioavailable tocopherol) とに分けられている, 17). すなわち, 赤血球中 の Toc 量は bioavailable Toc の指標 ${ }^{15,19)}$ となるが，血 清 Toc はむしろ脂質プール内の Toc 量を反映している ので高脂血症や肥満例 ${ }^{4,5)}$ では血清 Toc 值が増加するが, 肝臓, 心臓, 赤血球, 肺等諸臓器に含まれるbioavailable Toc 值は反って減少する.

今回の乳用雄においても, 血清 Toc 值は血清の TL および PL 濃度と高い相関（ $\gamma=0.67$ および $\gamma=0.65 ）$ を示す等, Toc の脂質プールへの移行性が良好なこと を示唆したが, いっぽう同月齢の乳用雌と比べても肥育 飼料の過給で急速に体重が増加して体脂肪蓄積が進んだ IV〜VI期の乳用雄では，血清脂質成分（TL，PL，TC， $\mathrm{EC})$ は増加したが赤血球 Toc 值は反って明瞭に減少し た.これらの所見は牛でも人と同様に, 肥満すなわち体 脂肪が蓄積すると脂溶性ビタミンとしての Toc の脂肪 組織への移行量が著るしく増加する結果, 赤血球 Toc 值が減少することを示したものであり，この点からみて 赤血球 Toc 值の測定が牛のボディコンディション ${ }^{7,29)}$ の 
乳用雄子牛と雌子牛の発育段階における血清のビタミン $\mathrm{A}, \mathrm{E}$, セレニウム, 脂質分画および血液グルタチオンペルオキシダーゼ活性の変化

判定のよい指標となりうる可能性を十分伺わせたが, 詳 しくは今後の検討課題であると考えられる.

血清ビタミン A は乳用雄では肥育が進むIV〜VI期に おいて乳用雌と比べ有意な低值を示したが，その原因は 肥育期に不断給餌の状態で過給した配合飼料のビタミン A 含量が本来少いことが関係したと思われる.なお, 乳用雄の I, II 期の血清レチニルパルミテート值が特に 高值を示したのは, この時期に給与したビタミン $\mathrm{AD}_{3} \mathrm{E}$ 剂の影響と考えられる.

いっぽう, 乳用雄では特に赤血球 Toc 值が低下した III期以降において血清 Se と血液 GSH-Px 活性は増加 の傾向がみられたが，原因はこの時期に Se 含量の多い 濃厚飼料 ${ }^{9)}$ を摂取したためであり，その結果 Se を構成 成分とする血液 GSH-Px 活性も増加したものと考える. これに対し, 乳用雌では本来 Se 含量の低い粗飼料の給 与が主体であったため，特に V〜VI期に血清 Se 值（平 均 $40 \mathrm{ppb}$ 以下）と血液 GSH-Px 活性值（平均約 $12 \mathrm{e} . \mathrm{u}$ 以下) の低下が明瞭であった. Toc と Se (GSH-Px) は 脂質の過酸化抑制 ${ }^{18)}$, 細胞膜系の保護と安定化 ${ }^{6,10)}$ の他, ビタミン E と併せて乳房炎の予防等の生体防衛 ${ }^{12)}$ に 関与することが知られているので, 諸疾患の発生防止の ためにも乳用雄では Toc, 乳用雌では Se の給与につい て考慮する必要のあることが今回の成績から示唆された。

\section{引用文献}

1）阿部皓一, 石橋恭子, 大前雅彦, ほか：ビタミン, 51, $275 \sim 280$ (1977).

2）阿部皓一, 勝井五一郎: 栄養之食糧, $28,277 \sim 280$ (1975).

3) 阿部皓一, 大前雅彦, 阿部 靖, ほか：ビタミン, 53, $385 \sim 390$ (1979).

4) Bieri J. G. and Evarts R. P. : Proc. Soc. Exp. Biol. Med., 149, 500 502 (1975).

5) Bieri J. G. Evats R. P. and Thorg, S.: Am. J. Clin, Nutr., 30, 686 690 (1977).

6) Chow C. K. and TApple A. L.: Lipid, 7, 518 524 (1972).

7) GaAl T., Roberts C. J. and Reid I. M.: Vet. Rec., $113,53 \sim 54$ (1983).
8) Higgins R. J. and Anderson W. S.: Vet. Rec., $113,461 \sim 463$ (1983).

9）一条 茂, 納 敏, 竹田孝夫：日獣会誌, 41,565 〜 570 (1988).

10）五十嵐修：ビタミン学， 1，208～216, 東京化学同 人 (1986).

11）石橋恭子, 阿部皓一, 大前雅彦：ビタミン, 51 , 415 (1977).

12) Ivandija L.: Vet. Bull., 56, 517 (1986).

13）金田尚志, 宮沢陽夫：過酸化脂質実験法, $80 \sim 117$, 医歯薬出版 (1985).

14）加納康彦, 沢崎 徹, 沢崎 坦, ほ加: 日畜会報, 47, $397 \sim 401$ (1967).

15）北川 真, 美濃 真：日本臨床, 43 (秋季臨時増 刊) $418 \sim 422$ (1985).

16）北川政幸：栄養生理研報，27，119～129（1985）.

17) Machlin L. J., Keating j., Nelson, J., et al.: J. Nutr., 109, 105 110 (1979).

18）松尾光芳：過酸化脂質と生体. $13 \sim 44$, 学会出版 センター (1985).

19）毛利佳世, 江坂知美, 五十嵐脩: 日本栄養 - 食糧学 会誌, 37, 441 ４46 (1984).

20）森田二郎, 堀平四郎, 南 高夫, ほか：鳥大農研報, $36, \quad 19 \sim 27$ (1984).

21) Morrows D. A.: J. Dairy. Sci., 59, 1625 1629 (1975).

22）本好茂一, 内貴正治, 牛見忠蔵, ほか：臨床獣医, 1, $15 \sim 36$ (1983).

23）西邑隆徳, 佐藤幸信, 川崎勉, ほか: 新得畜試研 報, $36,19 \sim 27$ (1984).

24) Olson O. E,: J. AOAC., 52, 627 634 (1969).

25) Olson O. E,: Palmer I. S. and Cary E. E.: J. AOAC., 58, 115 121 (1975).

26）大脇雄三, 鈴木慶信, 香本頴利, ほか：家畜診療, 214, $16 \sim 22$ (1981).

27) Paglia D. E. and Valentine W. N.: J. Lab. Clin, Med., 70, 158 169 (1969).

28）竹下 潔, 吉田正三郎, 田中彰治, ほか：東北農試 研報, 50, 99 111（1975）.

29) Tgopponen j., Hakkarainen j., Juokslahti T., et al.: Am J. Vet. Res., 45, 1790 1794 (1984).

30）山崎敏雄, 小沢 忍, 塩谷康生: 中国農試報告, B 19, $39 \sim 51$ (1972). 